\title{
Experiment Study of Wave Force on Parapet of Inclined Breakwater Under Cover
}

\author{
Xingkai Pan ${ }^{1, a}$, Jingsong Gui ${ }^{1, b *}$, Xianying Shi ${ }^{1}$, Lingling Chen ${ }^{2}$ \\ ${ }^{1}$ College of Ocean and Civil Engineering, Dalian Ocean University, Dalian, Liaoning, China. \\ ${ }^{2}$ School of Civil Engineering and Architecture, Tianjin University, Tianjin, China. \\ a1138657572@qq.com, bouijs@163.com ("corresponding author)
}

KEY WORDS: Inclined breakwater; parapet; model test; wave force.

ABSTRACT: In the case of the inclined breakwater covered, the wave force acting on the parapet is reduced. China's "Breakwater Design and Construction Norms", there is stipulation on the calculation of the parapet, when the parapet before the cover and cover the width and height of 2 rows of 2 layers of dolosse, the wave force on parapet can be multiplied by the reduction factor $0.6 \sim 0.7$, But for parapet is full of accropode, large stone blocks and other surface protection, the wave force reduction is not described. In this paper, physical model test, the wave force acting on the parapet under different wave parameter and filled with accropode and large stones are measured and compared with the results of the current code. The results show that: In the case of full accropode and large stone, the wave force reduction coefficient of 0.8 is more suitable. It can be used for reference for design.

\section{INTRODUCTION:}

The breakwater is an important hydraulic structure in coastal engineering. The inclined breakwater has the advantages of weak wave reflection, low bearing capacity of foundation, simple construction, and is widely used in ocean, river and city bank protection ${ }^{[1]}$. At present, China's "Harbor Hydrologic Norms",[2] in the calculation of the inclined breakwater parapet wave force method: the incident wave in the parapet on the surface pressure generated by the uniform distribution along the height, After determining the average pressure $\bar{p}$ and wave height $d_{1}+Z$, The total horizontal wave force is calculated by the formula of $P=\bar{p}\left(d_{1}+Z\right)$. But the pressure generated by wave action along the surface of the parapet was evenly distributed phenomenon does not match the actual situation. Ying Wang ${ }^{[3]}$ through the physical model tests were measured before the parapet uncovered wave conditions, and with the "Harbor Hydrological Norms" in the calculation methods were compared, the results show that the standard wave force calculation is far less than the measured wave force. Yuliang $\mathrm{Liu}^{[4]}$ contrasted the different test results and the horizontal force calculated by the standard method under the different coverings before the breakwater parapet. The results show that the difference between the horizontal force and the measured value of the breakwaters in the half-cover and full- $20 \%$.

Spain Francisco L.Martin ${ }^{[5]}$ and others in a series of experimental observations based on the proposed calculation of the inclined breakwater parapet wave force method. When the waves are broken on the slope of the protective surface, the wave force on the parapet can be divided into the dynamic pressure $p_{d}$ and the reflecting pressure $p_{r}$, both of which are linear with the water tongues formed by the climbing of the incident wave. However, Francisco L. Martin have only studied the application of parallelepiped block screening, while other forms of block cover have not been studied, so further study is needed. 
On the basis of the physical model, the different types of shield blocks were placed in front of the top of the breakwater, and the measured data under different working conditions were collected and compared with the wave force on the inclined breakwater parapet, which was calculated in the "Harbor Hydrologic Norms" And obtains the reduction coefficient, which provides more reference for the actual project. It is very important to ensure the safe operation of the project and the economic benefit after construction.

\section{TEST CONDITIONS}

\section{Test equipment}

The experiment was carried out in the Key Laboratory of Coastal Engineering of Dalian Ocean University. The effective size of the tank was $40 \mathrm{~m}$ long, $0.7 \mathrm{~m}$ wide and $1 \mathrm{~m}$ deep. One end of the water tank is equipped with motor generators irregular wave machine, can generate a regular cycle of $0.5 \sim 5 \mathrm{~s}$ between the regular waves, irregular waves and other waves. Trough the end of the installation of vertical energy dissipation grid, so as not to wave reflection. The DS-30 wave acquisition and processing system developed and produced by the Tianjin Water Conservancy Research Institute was used in the experiment. The breakwater model was made of cement mortar and the part used to measure the wave pressure distribution was made of plexiglass.

\section{Test Content}

The regular waves are used in the experiment. The water depth of the project is $14.25,15$ and $15.5 \mathrm{~m}$, and the incident wave height is $3.75,4.5$ and $5 \mathrm{~m}$, and the incident wave cycle is 8,10 and $12 \mathrm{~s}$. The cross-section model is designed according to the gravitational similarity criterion. The dimension of the section is geometrically similar. The geometric scale is 25 , which the depth scale, wave height scale, and wavelength scale are 25 and the period scale is $\lambda_{t}=5$.

Test in the parapet on the wave surface set up five measuring points, in the bottom of the parapet set up five measuring points. The specific measuring point arrangement is shown in Fig1.

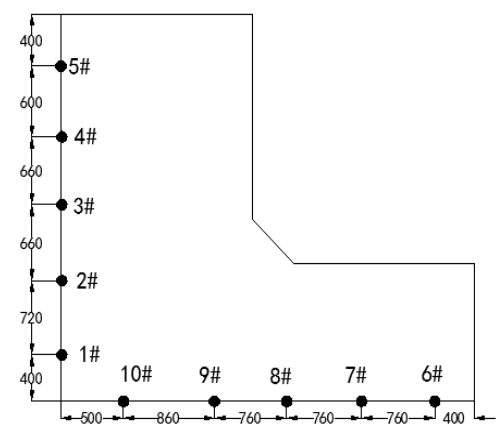

Fig 1 The actual project parapet pressure measuring point layout(Unit: $\mathbf{m m}$ )

\section{Measurement Methods}

The DS-30 data acquisition and processing system is used tomeasure the wave force. The system consists of computer, force measuring probe and data acquisition box. The wave force on each point on the parapet of the inclined breakwater is measured directly by the force measuring probe, which is placed inside the parapet and is level with the surface of the parapet. The wave forces on the parapet were measured in 8 working conditions, among which working condition 1 to working condition 4 were the measured values of wave front and bottom wave pressure under the protection of accropode. 


\section{TEST RESULTS}

The statistical distribution of the pressure at each measuring point at the maximum moment of the horizontal force is obtained and the total force of the unit length and the total force of the float are calculated. The test results are shown in Table 1.

In Accordance with the Standard Method to Calculate the Parapet Wave Force

According to the (JTJ-142-2-2013) "Harbor Hydrological Norms", the calculation method of the wave force of the top wall of the slope type building, the average wave pressure of the inclined breakwater parapet under the wave action is calculated as follows:

$$
\bar{p}=0.24 \gamma H K_{p}
$$

Where: $\bar{p}$ is the average pressure strength $(\mathrm{kPa}) ; \mathrm{L} / \mathrm{H}$ for the dimensionless parameter $\xi$ and Potain $L / H$ on the average pressure coefficient.

The dimensionless parameters are calculated by $\zeta=\left(\frac{d_{1}}{d}\right)\left(\frac{d}{H}\right)^{2 \pi H / L}, \quad \zeta_{b}=3.29\left(\frac{H}{L}+0.043\right)$.

This provision applies only to the uncovered condition of the parapet. According to the calculation method given in the norms, the wave force acting on the parapet by the test wave element is calculated. The results are shown in Table 2.

Wave Force Results of Comparative Analysis

From the table 1 dates can be seen clearly that the wave force acting on the wave front of the parapet increases first and then decreases from the bottom to the top, because the wave force has a major effect area near the still water level ${ }^{[6]}$,The regional wave force, waves in the parapet before climbing, consuming most of the energy, its rapid reduction in the pressure on the parapet. The bottom of the parapet of the buoyant force, the largest side of the upstream face, The farther away from the upstream face, the smaller the float force. This is because the main area of the wave action concentrated in the bottom of the parapet on the side of the upstream face, the region by the maximum wave force, wave propagation in the parapet at the bottom of the energy is gradually being dissipated, so the buoyant force from large to small changes trend.

Comparing the measured values of wave force under the same working conditions with the calculated values, the reduction coefficient of the wave force in the case of two rows of accropode and large stone shield can be obtained. From the data in Table 2, it can be seen that compared with the uncovered condition of the parapet, the breakwater in the front of the parapet placed two rows of accropode protection conditions, the horizontal wave force reduction factor of 0.667 , The average reduction coefficient of buoyant force is 0.798 . Parapet in the large stone cover conditions, the horizontal wave force reduction factor of 0.714 , The average reduction coefficient of buoyant force is 0.761 .

"Breakwater Design and Construction Norms" has been provided, when the parapet before the block cover and cover the width and height to meet the two rows of two layers, the role of the parapet of the horizontal wave force and buoyant force multiplied by the reduction factor $0.6 \sim 0.7{ }^{[7]}$. And usually in engineering design, when use accropode as the breakwater surface, are placed in two rows of a layer . Therefore, it is very unsafe to determine the wave force acting on the parapet for stable calculation if the wave break-out condition of the breakwater is not observed by experiment, but subjectively using the reduction factor of 0.6 in the specification. 
Table 1 Parapet of total force when the maximum point of the measurement of synchronous wave pressure

\begin{tabular}{|c|c|c|c|c|c|c|c|c|c|c|c|c|}
\hline \multicolumn{10}{|c|}{ The point pressure $(k P a)$} & \multicolumn{1}{c|}{$\begin{array}{c}\text { Total wave force } \\
(\mathrm{kN} / \mathrm{m})\end{array}$} \\
\hline $\begin{array}{c}\text { Conditio } \\
\text { n number }\end{array}$ & $\mathrm{P} 1$ & $\mathrm{P} 2$ & $\mathrm{P} 3$ & $\mathrm{P} 4$ & $\mathrm{P} 5$ & $\mathrm{P} 6$ & $\mathrm{P} 7$ & $\mathrm{P} 8$ & $\mathrm{P} 9$ & $\mathrm{P} 10$ & $\begin{array}{c}\text { Horizontal } \\
\text { force }\end{array}$ & $\begin{array}{c}\text { Floating } \\
\text { force }\end{array}$ \\
\hline 1 & 26.59 & 38.32 & 51.73 & 23.43 & 15.81 & 6.91 & 13.17 & 20.72 & 25.75 & 36.06 & 89.85 & 64.75 \\
\hline 2 & 31.49 & 64.57 & 55.81 & 52.71 & 25.05 & 10.76 & 12.22 & 21.77 & 26.81 & 45.87 & 133.45 & 71.36 \\
\hline 3 & 33.79 & 62.30 & 65.82 & 73.35 & 31.77 & 11.43 & 14.51 & 24.36 & 30.59 & 48.44 & 154.33 & 79.49 \\
\hline 4 & 53.55 & 70.56 & 84.35 & 22.98 & 14.44 & 14.94 & 15.26 & 25.76 & 32.34 & 45.60 & 142.44 & 82.66 \\
\hline 5 & 52.08 & 65.74 & 45.19 & 25.32 & 18.41 & 8.78 & 11.17 & 14.59 & 29.62 & 44.89 & 115.41 & 66.21 \\
\hline 6 & 65.24 & 72.47 & 53.82 & 27.81 & 18.35 & 6.28 & 6.97 & 11.29 & 21.58 & 39.53 & 132.04 & 50.74 \\
\hline 7 & 38.50 & 65.93 & 44.28 & 41.02 & 6.04 & 8.26 & 10.17 & 16.45 & 27.52 & 40.19 & 116.23 & 62.94 \\
\hline 8 & 61.24 & 77.73 & 55.31 & 12.07 & 6.08 & 11.93 & 13.63 & 22.96 & 41.71 & 67.16 & 121.61 & 95.01 \\
\hline
\end{tabular}

Table 2 Standard method to calculate the parapet wave force results and measured value reduction factor

\begin{tabular}{|c|c|c|c|c|c|c|c|}
\hline \multirow{2}{*}{$\begin{array}{l}\text { Type of } \\
\text { cover }\end{array}$} & \multirow{2}{*}{$\begin{array}{c}\text { Condition } \\
\text { number }\end{array}$} & \multicolumn{2}{|c|}{$\begin{array}{l}\text { Specification of wave } \\
\text { forces }(\mathrm{kN} / \mathrm{m}))\end{array}$} & \multicolumn{4}{|c|}{ Measured reduction factor } \\
\hline & & $\begin{array}{l}\text { Horizontal } \\
\text { force }\end{array}$ & $\begin{array}{l}\text { Floating } \\
\text { force }\end{array}$ & $\begin{array}{l}\text { Horizontal } \\
\text { force }\end{array}$ & & $\begin{array}{l}\text { Floating } \\
\text { force }\end{array}$ & \\
\hline \multirow{4}{*}{$\begin{array}{l}\text { Two rows } \\
\text { of } \\
\text { accropode }\end{array}$} & 1 & 139.64 & 84.67 & 0.643 & \multirow{4}{*}{$\begin{array}{c}\text { average } \\
\text { value of } \\
0.667\end{array}$} & 0.765 & \multirow{4}{*}{$\begin{array}{c}\text { Average } \\
\text { value of } \\
0.798\end{array}$} \\
\hline & 2 & 186.75 & 90.72 & 0.715 & & 0.787 & \\
\hline & 3 & 242.13 & 96.77 & 0.637 & & 0.821 & \\
\hline & 4 & 211.72 & 100.80 & 0.673 & & 0.820 & \\
\hline \multirow{4}{*}{$\begin{array}{l}\text { Large } \\
\text { stone }\end{array}$} & 5 & 137.15 & 83.16 & 0.841 & \multirow{4}{*}{$\begin{array}{c}\text { average } \\
\text { value of } \\
0.714\end{array}$} & 0.796 & \multirow{4}{*}{$\begin{array}{c}\text { average } \\
\text { value of } \\
0.761\end{array}$} \\
\hline & 6 & 186.75 & 90.72 & 0.707 & & 0.559 & \\
\hline & 7 & 172.66 & 75.60 & 0.673 & & 0.833 & \\
\hline & 8 & 191.29 & 110.80 & 0.636 & & 0.857 & \\
\hline
\end{tabular}

\section{CONCLUSIONS}

In this paper, the wave forces at the inclined breakwater parapet under three kinds of different depths, three kinds of wave heights, three different periods and wave action are measured by physical model test, and the difference between the calculated results of the "Harbor Hydrological Norms" And provide the reference for the design of inclined breakwater with different types of protection.

(1) The results of comparative analysis show that there is a significant difference between the total horizontal force magnitude and the measured results, which is based on the pressure distribution of the front surface of the parapet calculated by the current norms in the existing "Harbor Hydrographic Norms".

(2) The wave pressure of the parapet surface wave was regarded as uniform distribution by the standard method. The test results showed that the wave pressure had a wave action in the vicinity of the still water level in the front of the parapet, in which the wave force was relatively large. The wave force decays rapidly with the increase of the height of the action point. 
(3) The test results show that the application of two rows and one layer of accropode and large stone as a wave block, the wave reduction coefficient of 0.8 to take more reasonable, can also have a certain wave force reduction effect.

\section{REFERENCES}

[1]Yuanzhan Wang. Port and Coastal Hydraulic Structures(2012). Tianjin: People's Communications Press.

[2] JTJ 142-2-2013 harbor hydrological norms [S].

[3] Ying Wang(2007). "Experimental Research of Wave Loads on Arc Crown Wall”[Master's Thesis].Shanghai: Shanghai Jiaotong University.

[4] Yuliang Liu(2010). "Influence of Armor of Inclined Breakwater on Wave Force on Parapet" [J] Water Transport Engineering, (8): 36-38.

[5] Martin F L, Losada M A, Mcdina R(1999). "Wave loads on rubble mound break water crown walls". Coastal Engineering, 37 (2): 149-171.

[6] Dingyong Yu(2012). "Study on Wave Force Calculation Method of Deepwater Inclined Breakwater Parapet”.Periodical of Ocean University of China .42 (1-2): 136-140.

[7] JTS 154-1-2011. Breakwater Design and Construction Norms. 